\title{
Solid inorganic peroxy compounds in environmental protection
}

\author{
Barbara Walawska1, Joanna Gluzińska', Korneliusz Miksch ${ }^{2}$, Jolanta Turek-Szytow ${ }^{2}$ \\ ${ }^{1}$ Institute of Inorganic Chemistry, ul.Sowińskiego 11, 44-101 Gliwice, Poland, e-mail: basiawal@ichn.gliwice.pl \\ ${ }^{2}$ The Silesian University of Technology, Faculty of Energy and Environmental Engineering, ul. Akademicka 2, \\ 44-100 Gliwice, Poland
}

\begin{abstract}
The paper presents a solid inorganic peroxy compounds description (calcium peroxide, magnesium peroxide and sodium percarbonate) focused on the properties and environmental application, particularly for the degradation of polycyclic aromatic hydrocarbons (PAHs) and phenols in soil environment. Modern technological processes require the use of compounds that are safe for the environment, non-toxic, easily degradable to the products, which themselves have no adverse environmental effect. Peroxides, as the chemical compounds, produce an effect on the enzymatic activity of the environment into which they are introduced. A good indicator of the activity of soil, bottom sediment or activated sludge, may be the dehydrogenase activity, which is a reflection of the general physiological state of microorganisms. Peroxides can be applied both in a pure form, as well as in mixtures with certain other groups of compounds. To enhance their efficiency they can be mixed with nitrogen, phosphorus or potassium carrying compounds.
\end{abstract}

Keywords: active oxygen, peroxy compounds, environmental protection, PAHs.

Presented at VII Conference Wasteless Technologies and Waste Management in Chemical Industry and Agriculture, Międzyzdroje, 12 - 15 June, 2007.

\section{INTRODUCTION}

The environmental protection technologies make a growing use of peroxy compounds (calcium peroxide $-\mathrm{CaO}_{2}$, magnesium peroxide $-\mathrm{MgO}_{2}$ ) and other compounds that contain the peroxide group, e.g. sodium percarbonate $\mathrm{Na}_{2} \mathrm{CO}_{3} \cdot 1 / 2 \mathrm{H}_{2} \mathrm{O}_{2}$. These compounds are classified as chemical oxidizers, just like hydrogen peroxide $-\mathrm{H}_{2} \mathrm{O}_{2}$, the latter now being supplanted by solid compounds with active oxygen. Under the action of acids or in aqueous solutions these compounds hydrolyze and evolve hydrogen peroxide, liberating thereby active oxygen. Thus, they find various applications in the protection of soil, water and air ${ }^{1}$, particularly in the processes of pollutant oxidation or oxidative bioremediation. Such compounds are highly alkaline. The content of active oxygen in commercial products varies in a wide range - from $8-10 \%$ $\left(\mathrm{MgO}_{2}\right)$ to $17-18 \%\left(\mathrm{CaO}_{2}\right) \cdot \mathrm{Na}_{2} \mathrm{CO}_{3} \cdot 1 / 2 \mathrm{H}_{2} \mathrm{O}_{2}$ contains minimum $13 \%$ active oxygen.

\section{PREPARATION OF PEROXY COMPOUNDS}

There are a number of preparation methods of compounds with active oxygen, the source of which is hydrogen peroxide. Calcium peroxide can be obtained using wet or dry methods ${ }^{\mathbf{1 2}}$. Available literature, mostly patents, provides sparse descriptions of calcium peroxide preparation, most of them being wet methods. The second substrate, calcium, is introduced in wet methods in the form of the solutions of calcium chloride or nitrate, or in the form of calcium hydroxide suspension. In dry methods, dry calcium oxide or hydroxide is used ${ }^{10,11}$. The product obtained while using these methods consists mainly of a mixture of calcium hydroxide and peroxide with a various content of active oxygen.

In dry methods, as compared to the wet methods, which are more environment friendly (no wastewater), calcium peroxide is obtained in the following reaction:

$$
\mathrm{CaO}_{(\mathrm{s})}+\mathrm{H}_{2} \mathrm{O}_{2(\mathrm{l})} \rightarrow \mathrm{CaO}_{2(\mathrm{~s})}+\mathrm{H}_{2} \mathrm{O}+\mathrm{Q}
$$

or

$$
\mathrm{Ca}(\mathrm{OH})_{2(\mathrm{~s})}+\mathrm{H}_{2} \mathrm{O}_{2(\mathrm{l})} \rightarrow \mathrm{CaO}_{2(\mathrm{~s})}+2 \mathrm{H}_{2} \mathrm{O}+\mathrm{Q}
$$

Magnesium peroxide, like calcium peroxide, is obtained from the corresponding oxide or hydroxide. This product, however, contains much less active oxygen: ca. 10\%. Both calcium peroxide and magnesium peroxide are among the most stable peroxy compounds. The main applications of calcium and magnesium peroxide are associated with their slow decomposition under the effect of moisture, according to the following reaction equation:

$\mathrm{CaO}_{2}+\mathrm{H}_{2} \mathrm{O} \rightarrow \mathrm{Ca}(\mathrm{OH})_{2}+1 / 2 \mathrm{O}_{2}$

$\mathrm{MgO}_{2}+\mathrm{H}_{2} \mathrm{O} \rightarrow \mathrm{Mg}(\mathrm{OH})_{2}+1 / 2 \mathrm{O}_{2}$

The rate of active oxygen generation depends on the physical and chemical properties of the surrounding environment. In an aqueous environment of lower $\mathrm{pH}$, calcium and magnesium peroxides decompose as illustrated by the reactions:

$$
\begin{aligned}
& \mathrm{CaO}_{2}+2 \mathrm{H}^{+} \rightarrow \mathrm{Ca}^{2+}(\mathrm{aq})+\mathrm{H}_{2} \mathrm{O}_{2} \\
& \mathrm{MgO}_{2}+2 \mathrm{H}^{+} \rightarrow \mathrm{Mg}^{2+}(\mathrm{aq})+\mathrm{H}_{2} \mathrm{O}_{2} \\
& \mathrm{H}_{2} \mathrm{O}_{2} \rightarrow \mathrm{H}_{2} \mathrm{O}+1 / 2 \mathrm{O}_{2}
\end{aligned}
$$

The above reactions are of importance in the applications of calcium and magnesium peroxides as the sources of active oxygen. The decomposition rate depends not only on the $\mathrm{pH}$ value of the environment, but also on the decomposition products. The relationship between the degree of peroxide decomposition and the $\mathrm{pH}$ was investigated on calcium peroxide obtained at the Institute of Inorganic Chemistry by adding nitric or orthophosphoric acid to a suspension of calcium peroxide. To this end, a $2 \%$ calcium peroxide suspension was prepared, from which, upon lowering the $\mathrm{pH}$ to an appropriate level, the solid phase was separated and the concentration of active oxygen and calcium was determined. The results obtained, both for active oxygen as well as calcium concentration, differ widely, particularly at the $\mathrm{pH}$ below 10 . This is 
associated with the differing solubilities of the products obtained in the course of orthophosphoric or nitric acid introduction. Addition of orthophosphoric acid, at high $\mathrm{pH}$ values, causes a reduction in calcium concentration and the precipitation of insoluble orthophosphates. Further $\mathrm{pH}$ reduction to below 8 , leads to increased calcium concentration. The concentration of active oxygen increases throughout the entire investigated range of the $\mathrm{pH}$ change. When nitric acid is used, no decrease of calcium ion concentration is observed, but quite the opposite, the concentration increases, particularly at the $\mathrm{pH}$ below 9 . This is also associated with a significant increase in active oxygen concentration in water. In this case no insoluble salts are formed, and the concentration of active oxygen is also higher. The difference in active oxygen concentration at the same $\mathrm{pH}$, depending on the acid used, is substantial, particularly as the latter is lowered. At the $\mathrm{pH}=8$ that concentration is $112 \mathrm{ppm} \mathrm{O}_{2}$ when orthophosphoric

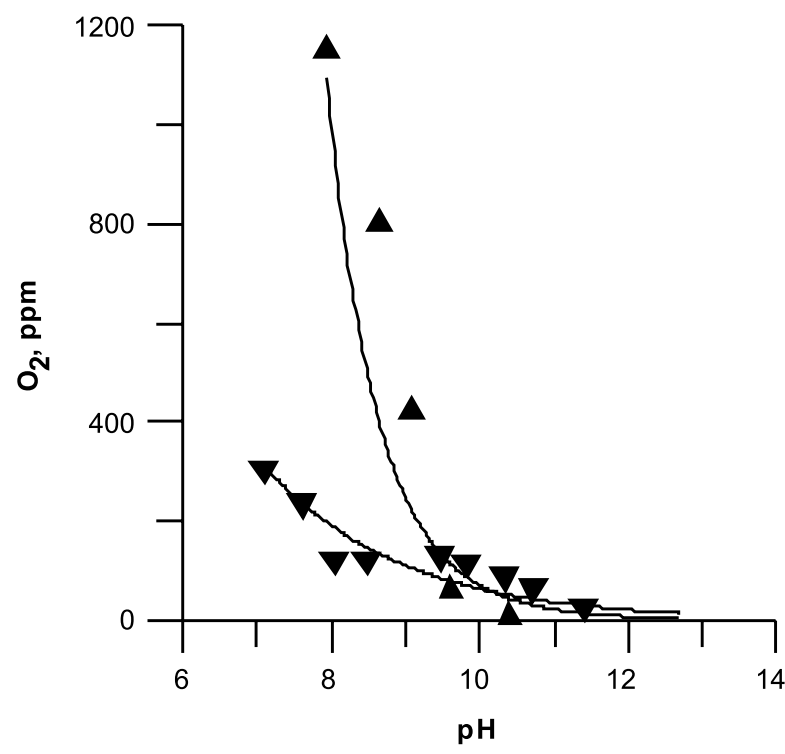

Figure 1. The release of active oxygen at various $\mathrm{pH}$ values $\left(\boldsymbol{\nabla}-\mathrm{H}_{3} \mathrm{PO}_{4}, \boldsymbol{\Delta}-\mathrm{HNO}_{3}\right)$

acid is used, and $1150 \mathrm{ppm} \mathrm{O}_{2}$ when nitric acid is used. This is illustrated in Fig. 1.

Sodium percarbonate is a less stable compound - it is a hydrogen peroxide adduct of sodium carbonate. This compound is highly soluble in water (ca. $140 \mathrm{~g} / \mathrm{l}$ ). It is obtained mainly while using wet methods by crystallization or granulation in a fluidized bed from sodium carbonate solution and hydrogen peroxide, as illustrated by the following equation:

$2 \mathrm{Na}_{2} \mathrm{CO}_{3(\text { sol })}+3 \mathrm{H}_{2} \mathrm{O}_{2(\mathrm{l})} \rightarrow 2 \mathrm{Na}_{2} \mathrm{CO}_{3} \cdot 3 \mathrm{H}_{2} \mathrm{O}_{2}$

\section{APPLICATION IN ENVIRONMENTAL PROTECTION}

Due to their scarce solubility in water, decomposition of calcium and magnesium peroxides under the effect of moisture is very slow, which guarantees gradual and continuous release of hydrogen peroxide, which in the further course becomes a source of free radicals (chemical oxidation) and oxygen (aerobic conditions for microorganisms). This component is desirable, for instance, in the processes that occur in the soil (fertilizer component) and in the oxidative bioremediation of the soil ${ }^{2}, 13,14$.

Calcium and magnesium peroxides are mainly used:
- to raise the efficiency of the treatment of municipal and industrial wastewater; to thicken and condition sludges, to dewater sludges, to deodorize municipal sludge cake $^{5,18}$,

- to control odour - as a component of an agent for $\mathrm{H}_{2} \mathrm{~S}$ removal from the soil, water and air $^{6}$, to remove odour from industrial waste gases",

- to treat water from mines,

- as ingredients of disinfecting preparations used in surgery and dentistry ${ }^{8}$, in modern tooth-cleaning preparations (calcium or magnesium peroxide is a whitening agent, and the released hydrogen peroxide removes discoloration and tartar),

- as the basic component (up to 95\%) of an agent used in composting plants ${ }^{9}$ (increases microbial activity, reduces or completely eliminates the need to agitate the material being composted),

- as promoters of direct oxidation of aliphatic ${ }^{15}$ and aromatic hydrocarbons in wastewater and soil ${ }^{16}$,

- to oxygenate the bottom sediments ${ }^{17,34}$ and enhance the process of self-purification of water (the improvement of oxygen conditions and prevention or elimination of the problems associated with „oxygen deficiency”),

- in fruit-growing, gardening and forestry to improve oxygen availability for the seeds and root systems and to increase the germination rate, root growth and crop yields ${ }^{32}$,

- as quality-improvers for bread baking (calcium peroxide only $)^{33}$.

Sodium percarbonate, as a highly water-soluble compound, finds use in oxidation processes and in oxidative bioremediation. Like the peroxides of calcium and magnesium, it is used in soil remediation, odour control, dechlorination, etc. Due to its high solubility it is a safer replacement for hydrogen peroxide. As an algicide it is used to selectively suppress the excessive growth of bluegreen algae in standing waters, i.e. lakes, ponds, drinking water reservoirs. Particularly prone to blooming are the small water bodies which are rich in nutrients, especially in phosphorus compounds. Algal blooms are caused by such blue-green algae as Anabaena flos-aquae, Aphanizomenon flos-aquae or Microcystis aeruginosa. Large quantities of blue-green algae in water bodies pose a hazard to human health and life, as the toxins produced by these unicellular organisms can damage the liver and nervous system of humans. Dosing of peroxides in various forms supplies oxygen to the processes of organic matter mineralization and stimulates the environmental self-purification.

Peroxides can be applied both in the pure form, as well as in the mixtures with certain other groups of compounds ${ }^{3}$. To enhance their efficiency they can be mixed with nitrogen, phosphorus or potassium carrying compounds. Of particular interest are the mixtures that contain phosphorus compounds, which decrease the rate of active oxygen release. These include potassium, ammonium and urea phosphates, which, in addition to controlling the oxygen release rate, also provide nutrients for biological processes. 


\section{THEORETICAL FUNDAMENTALS OF PEROXIDE AP- PLICATION IN BIOREMEDIATION OF THE SOIL CONTAMINATED WITH POLYCYCLIC AROMATIC HY- DROCARBONS (PAHS).}

Rapid progress has been recently observed in the elimination with the use of peroxy compounds of environmental pollution by oil derivatives. Much focus is placed on the study of degradation processes of polycyclic aromatic hydrocarbons (PAHs) in soil environment. In many cases these pollutants can efficiently be removed using biological, physical or chemical methods. The main problem, however, is not the reduction of high pollutant concentrations. This is achieved by implementing physical or chemical processes (extraction). The point to be solved is how to get rid of the remaining low concentrations of oil derivatives. Their elimination is a cumbersome process and requires ingenious chemical or biotechnological techniques. The latter, upon proper adaptation of microorganisms, are efficient and economically attractive. However, they require a long period of time to complete and, if the process runs inexpediently, they may lead to the generation of side products as harmful as the substrates. While most of PAHs are themselves not harmful, the products of their transformation can be highly toxic and/or mutagenic.

The growing knowledge of the metabolism of PAHs should enable managing the biological processes of their transformation in such manner as to avoid the formation of harmful intermediates and final products. It is known, for instance, that such undesirable circumstances may occur in the presence of fungi. PAH decomposition by fungi closely resembles the one occurring in humans and animals. The first stage of PAH metabolism by all eukaryotic organisms is the oxidation of the aromatic ring leading to the formation of an epoxy structure. This initial reaction consists in the addition of one of the atoms of molecular oxygen catalysed by the microsomal monooxygenase system. The epoxides formed undergo further transformations, with or without the participation of enzymes, resulting in toxic metabolites. Bacterial biodegradation of hydrocarbons is assisted by enzymes of the oxygenase, dehydrogenase and hydrolase groups. The first, initial reaction in the complex cycle of transformations consists in the oxidation of the hydrocarbon to a cisdihydrodiol by incorporating two atoms of molecular oxygen into the aromatic ring. This reaction is catalysed by dioxygenase. Cis-dihydrodiols undergo rearomatization in the presence of cis-dihydrodiol dehydrogenases resulting in derivatives with two hydroxyl groups. Cisdihydrodiols are oxidized to catechols. The latter constitute the substrate for another dehydrogenase, which enzymatically breaks the aromatic ring. Catechol can be oxidized via the ortho-pathway, where the bonds being cleaved are those between carbon atoms to which hydroxyl groups are linked, or via the meta-pathway, where the bonds being cleaved are those between one carbon atom linked to a hydroxyl group and an adjacent carbon atom. In the case of higher hydrocarbons the transformations are much more complex.

The description of the decomposition of PAHs given above indicates that detoxication effected by prokaryotes is much more advantageous than that effected by eukaryotes. In the course of the former, no toxic interme- diates are formed ${ }^{19}$. In general, the susceptibility of PAH to biological decomposition and the decomposition path depend on the type of hydrocarbon and on the environmental parameters ${ }^{20}$. The most important parameters include the abundance and the type of nutrients, $\mathrm{pH}$, oxygenation, humidity, temperature, biological factors, etc.

In order to shift the process towards the bacteria-induced rather than fungi-induced transformations (acid environment favours the latter), metal peroxides are used. These peroxides decompose in the environment and intensify the biological processes by improving oxygen availability $^{21}$. Various metal peroxides can be used: magnesium, calcium, zinc ${ }^{22,23}$, as well as hydrogen peroxide ${ }^{24,25}$. Such application in bioremediation of the contaminated soil is a recent development. A general review of bioremediation processes $^{26}$ drawn up in 2001 makes no mention of enhancing bioremediation by the so-called ORC's (oxygen release compounds), which include scarcely water soluble peroxides. Apart from the enhancement of bioremediation processes mentioned above, attempts were also made to use the substances that generate free radicals as a sole and radical method of oxidizing soil contaminants ${ }^{27}$. This, however, seems to be a less advantageous solution: it is less attractive in economic terms than a combination of partial chemical oxidation with biological processes. It is important to find a preparation, which is efficient on the one hand, and inexpensive on the other. In view of the above, in comparison to $\mathrm{H}_{2} \mathrm{O}_{2}$ or $\mathrm{ZnO}_{2}$, calcium peroxide $^{28,39}$ is more attractive, and it is also much less expensive than magnesium peroxide.

Examples of the reduction of organic carbon concentration in the soil induced by calcium peroxide are shown in Fig. 2. While organic carbon concentration in the reference soil remained constant, the observed decrease of organic carbon concentration in the soil samples with calcium peroxide added reached initially $1-3 \%$ (corresponding to a decrease by $10-30 \mathrm{~g} \mathrm{C} / \mathrm{kg}$ of soil), and 2 $-5 \%(20-50 \mathrm{~g} \mathrm{C} / \mathrm{kg}$ soil) on the seventh day of the experiment.

Assuming a 4\% loss of organic carbon during the 7 days of oxidation with calcium peroxide, the efficiency of the oxidation process was estimated at $240 \mathrm{mg} \mathrm{C} / \mathrm{kg} \mathrm{h}$.

The above approximate data seem to indicate that calcium peroxide might be used as a ready-to-use preparation, as an agent for neutralizing the effects of environmental impact, for enhancing microbiological decompo-

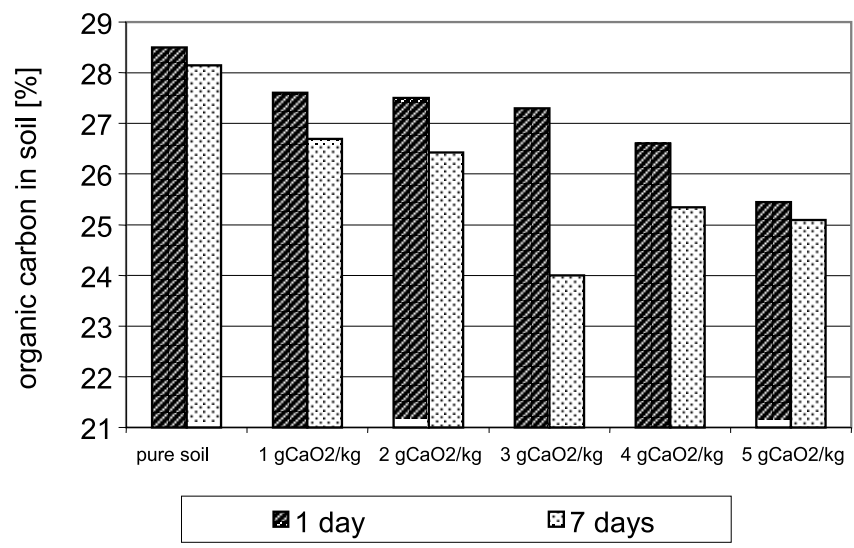

Figure 2. Organic carbon concentration after 1 and 7 days in the reference soil and in the soil with $\mathrm{CaO}_{2}$ added 
sition and for optimizing the environmental conditions (acidity neutralization and oxygenation). Similar effects would probably be achievable with other peroxides. The efficiency of the process will depend on the quantity and the manner of oxygen release within a given period of time.

Theoretical quantity of oxygen required for the oxidation of three-ring PAHs (anthracene and phenanthrene) is ca. $3 \mathrm{~g}$ per $1 \mathrm{~g}$ PAH. Assuming that the content of active oxygen in oxidizing compound, such as $\mathrm{CaO}_{2}$, is about $17 \%$, the required amount of that compound to completely mineralize the contamination would be ca. $18 \mathrm{~g}$ for every gram of that contamination. In theoretical considerations of the applicability of this solution one has to take into account the $\mathrm{pH}$ of the medium. Calcium peroxide $\left(\mathrm{CaO}_{2}\right)$ is a highly alkaline, scarcely water soluble compound. At a quantity of $0.5 \mathrm{~g} / \mathrm{l}$, upon partial dissolution, it changes the $\mathrm{pH}$ of water from 7 to 10 . Thus, the quantity of $\mathrm{CaO}_{2}$ added will be a compromise between oxygen demand and the change in $\mathrm{pH}$. Soils in Poland are classified mainly as acidic or weakly acidic. The use of peroxides as a procedure of "good agricultural practice” would not only contribute to the improvement of crop productivity, but would also optimise the soil $\mathrm{pH}$.

\section{EFFECT OF PEROXIDES ON THE ENVIRONMEN- TAL ENZYMATIC ACTIVITY}

Peroxides, as chemical compounds, produce an effect on the enzymatic activity of the environment into which they are introduced. It would be advisable to define the basic tools for tracking the changes reflecting the ways of modification of autochthonous microflora action.

The metabolic processes of micro-organisms are the indicators of such environmental biological activity are metabolic processes. These indicators include: the quantity of carbon dioxide released and oxygen consumed in respiration processes and enzymatic activity. The enzymatic activity is a more precise measure of the soil fertility and the productivity than other biological indicators, such as respiration intensity or micro-organism count. Enzymatic reactions form the basis of metabolism, determine the rate and the trend of metabolic transformations proceeding in the environment. All processes that take place in ecosystems have consequences in the changes in the rates of enzymatic processes ${ }^{30,31}$.

A good indicator of the activity of the soil, the bottom sediment, activated sludge, etc., may be the dehydrogenase activity, which is a reflection of the general physiological state of microorganisms. This is associated with the fact that metabolic paths of biological oxidation of substrates converge on the respiration chain. Therefore, the first indicator of the changes in the intensity of life processes is the decreased or increased dehydrogenase activity.

The relations discussed here can be illustrated in the graphical form (Fig. 3).

Dehydrogenase activity is therefore an indicator of the changes that proceed in the environment depending on the process of transformation of mainly organic compounds under the action of released reactive oxygen.

Determination of acid and alkaline phosphatase indicates the changes in enzymatic activity depending on the $\mathrm{pH}$ (calcium and magnesium peroxides, sodium

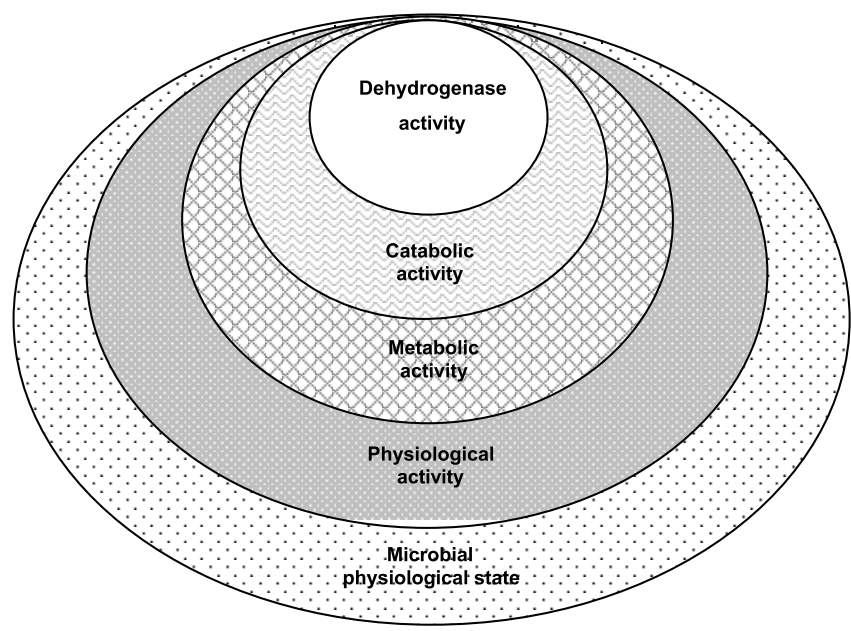

Figure 3. The microbial physiological state reflected in the enzymatic activity ${ }^{31}$

percarbonate are alkaline substances, whereas the products of polycyclic aromatic hydrocarbons decomposition are mostly acidic). This type of a combined determination of enzymes and physicochemical tests (the soil $\mathrm{pH}$ and the absorbing capacity) enables establishing the nature of the changes (sharp or gradual) and the significance thereof for the soil environment.

\section{SUMMARY}

Comprehensive application of peroxy compounds in environmental protection, particularly in soil bioremediation, is associated with their property - a long-lasting and gradual release of oxygen into the ecosystem. The metabolism of the ecosystem is comprised nearly exclusively of the metabolisms of the living organisms of the ecosystem (fauna, microorganisms, organic constituents, e.g. plant roots), and their enzymatic activity enables a proper course of purification processes - remediation. Every substance introduced into the environment, whether deliberately or not, disturbs the biological and chemical equilibrium in that environment, which can be utilized to stimulate or inhibit the microbial and floral activity. Peroxy compounds have a strong effect on two major environmental parameters: the $\mathrm{pH}$ and the quantity of oxygen supplied. Thus, the quantity of peroxides added should be a compromise between oxygen demand and the change in the environmental $\mathrm{pH}$.

One of the acute environmental problems is the contamination by various substances. Self-purification of the environment contaminated with, for instance, oil derivatives, is becoming increasingly impeded. The reason for this is the accumulation of hydrocarbons (PAHs in particular) in quantities exceeding the natural capacity of microbiota to process them. In comparison to self-purification in aquatic environment, the same process in the soil proceeds with great difficulty and is much slower. The difference results mainly from the lack of agitation in the soil, which obstructs intensive oxygenation and the homogenization of contaminants. This has a serious impact on biodegradation and mineralization processes.

At the time of growing the contamination of every environmental medium, the implementation in reclamation processes of the achievements of biotechnology, such as enhancing the decomposition by biostimulation, seem 
particularly promising (e.g. intensive oxygenation with the use of peroxy compounds). Increasingly the so-called Advanced Oxidation Processes (AOP's) are being implemented in the degradation of the most stubborn pollutants.

\section{ACKNOWLEDGMENTS}

This work was supported by the Research Project N 207 $07931 / 3765$.

\section{LITERATURE CITED}

(1) http://www.solvaychemicals.us/marketsapplications/ marketshidden/0,,40628-2-0,00.htm, 2007.

(2) Walawska B., Gluzińska J.: Calcium peroxide - properties and application for protection of environment, Chemistry for Agriculture, vol. 7, 17 - 21, Czech-Pol-Trade, Praga 2006.

(3) Patent US6268205, 2001.

(4) Bogoczek R., Molenda A.: Nadtlenek wodoru i jego addukty ze związkami małocząsteczkowymi, Przemysł Chemiczny, 1, 24 - 28, 2007.

(5) Buntner D., Żabczyński S., Miksch K.: Usuwanie farmaceutyków ze ścieków, Chemik, 2, 120 - 124, 2007.

(6) US Patent 6960330 (2005).

(7) US Patent 6932909 (2005).

(8) US Patent 5620527 (1997).

(9) US Patent 6277344 (2001).

(10) WO Patent 03/078313 A1 (2003).

(11) US Patent 6280495 (2001).

(12) Walawska B., Gluzińska J.: Nadtlenek wapnia jako źródło tlenu aktywnego, Przemysł Chemiczny, 8 - 9, pp., 2006.

(13) US Patent 5395419 (1995).

(14) US Patent 6569342 B1 (2003).

(15) Kao C. M., Chen S. C., Su M. C.: Laboratory column studies for evaluating a barrier system for providing oxygen and substrate for TCE biodegradation, Chemosphere, vol.44, issue 5, 925 - 934, 2001.

(16) Arienzo M.: Degradation of 2,4,6-trinitrotoluene in water and soil slurry utilizing a calcium peroxide compound, Chemosphere, vol.40, issue 4, 331 - 337, 2000.

(17) CN Patent 1490258 (2004).

(18) JP Patent 62057698 (1987).

(19) Reilley K. A., anks M. K., Schwab A. P.: Dissipation of policyclic aromatic hydrocarbons in the rhizosphere, J. Envir. Qual., 25, 1996.

(20) Maliszewska-Kordybach B.: The relationship between the properties of PAH and the rate of their disappearance from different soils, Toxicol. Environ. Chem., 66, 47 - 52.

(21) US Patent US 0058512 A (2005).

(22) Anonim.Applications of IXPER products. Solvay Chemicals Interox, Fluoridesand Minerals, 2004.

(23) Anonim. PermeOx Plus. Panther Technologies Inc., 2004.

(24) Vogt C., Alfreider A., Lorbeer H., Hoffmann D., Wuensche L., Babel W.: Bioremediation of chlorobenzenecontaminated groundwater in an in situ reactor mediated by hydrogen peroxide. J Contam Hydrol. 68(1 - 2)121 - 41, 2004.

(25) Zappi M., White K., Hwang H. M., Bajpai R., Qasim M.: The fate of hydrogen peroxide as an oxygen source for bioremediation activities within saturated aquifer systems. J. Air Waste Manag. Assoc. 50, 10, 1818 - 30, 2000.

(26) Vidali M.: Bioremediation. An overview. Pure Appl. Chem. 73, 7,1163 - 72, 2001.
(27) Prospekt. Groundwater and soil remediation. Advanced oxidation remediation technology. Aztech Technologies Inc, 2005.

(28) Cassidy D. P., Irvine R. L.: Use of calcium peroxide to provide oxygen for contaminant biodegradation in a saturated soil. J Hazard Mater. 69(1): 25 - 39, 1999.

(29) Kao C. M., Chen S. C., Wang J. Y., Chen Y. L., Lee S. Z.: Remediation of PCE-contaminated aquifer by an in situ two-layer biobarrier: laboratory batch and column studies. Water Res. 37(1), 27 - 38, 2003.

(30) Małachowska-Jutsz A. i WSP.: Aktywność enzymatyczna w glebie skażonej związkami ropopochodnymi w procesie jej detoksykacji, Biotechnologia, 1 (36), 1997.

(31) Miksch K.: Aktywność fizjologiczna drobnoustrojów w procesie osadu czynnego, Zeszyty Naukowe Politechniki Śląskiej, nr 735, Gliwice, 1983.

(32) www.solvaychemicals.us/pdf/IXPER/treetransplanting _TDS.pdf.

(33) http://www.solvaychemicals.us/static/wma/pdf/6/6/5/0/ IXP-03-002.pdf, 2007.

(34) Li H., Xu R., Obbard J. P.: Bioremediation of pyrene in marine beach sediments, Bioremediation Journal, 10(04): $169-177,2007$. 